\title{
今日の話題
}

\section{解䋊維形成と小胞体ストレス 「正常」なストレスを筋芽細胞の培養に利用する}

動物細胞の培養は約 100 年の歴史があり，合成培地と 動物血清を用いるようになってからも半世紀以上経つ。 培養細胞は大きく分けて, 生体から取り出した細胞塊を バラバラにした初代培養細胞と, 無限または多数回の細 胞分裂ができるようになった株化細胞の 2 種類ある．細 胞培養技術の基本はすでに確立しているといってよく， 様々な組織由来の細胞が培養可能である，筆者らは，骨 格筋の分化過程に打けるアポトーシスの研究を進めるう ちに，小胞体ストレス（後述）が分化過程に組み込まれ ている可能性を見いだしたため，細胞培養条件を設定す る上でストレスを考慮するという新たな試みを行なって いる。

骨格筋のもととなる筋芽細胞は最終分化によって筋繊 維（筋肉）となる．筋芽細胞はすでに筋肉へ分化するこ とを決定づけられている細胞であるが，筋繊維となるま でに大きな変化を経験する．筋芽細胞どうしは多数融合 して多核細胞（筋管）になり，細胞の中では筋肉特有の タンパク質（アクチン，ミオシンなど）が発現し筋原繊 維を形成する (図 1)。小胞体は筋小胞体に変換する。小 胞体は真核細胞がもつ細胞内小器官で, 膜タンパク質, 分泌タンパク質の合成，修飾，立体構造形成の場である 他，カルシウム貯蔵，脂質合成の場でもある．筋小胞体 は筋腹繊維を包み込むように発達し，カルシウムの放出 によって筋収縮を起こさせる。 そして筋原繊維が形成さ れ，細胞が収縮能を獲得してはじめて筋肉らしくなる. この筋管，筋繊維の形成過程における遺伝子発現調節の 変化や細胞内構造の変化を調べることによって分化機構 の理解が進んできた．また，シャーレの中でつくられる 筋繊維は薬剤のスクリーニングに用いられている，筋肉 は食事で摂取された糖を最む多く取り込む組織であ $り^{(1)}$, 筋繊維の糖取り込みや糖代謝を変える薬剤は糖尿 病に対する薬の開発につながることが期待されている。

シャーレの中で筋芽細胞を筋瀻維細胞にする試みも半 世紀ほど前に始まった，筋芽細胞は肧の筋節（筋肉にな る予定の領域）に多く含まれる他，成体の筋肉では筋衛 星細胞と呼ばれる未分化な細胞として存在する．株化細 胞としてはマウスの $\mathrm{C} 2 \mathrm{C} 12$ 細胞，ラットの L6 細胞など が樹立されている。これらの筋芽細胞をゼラチンなどで

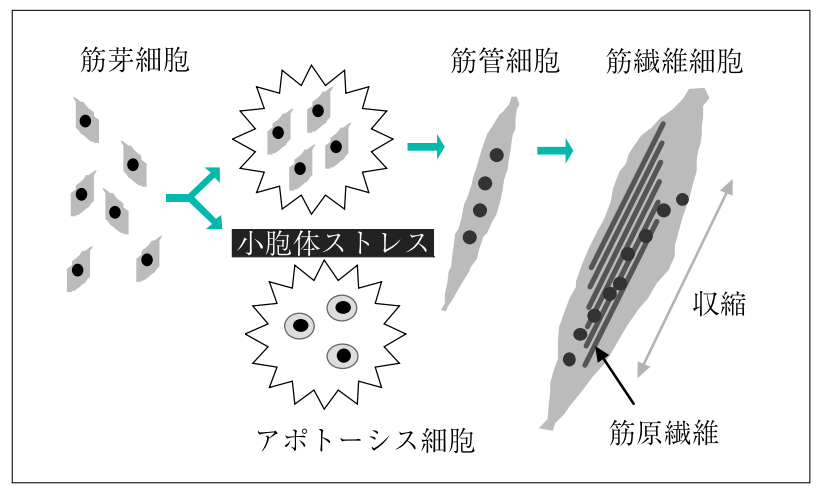

図 1 - 筋分化の過程

筋芽細胞は融合して筋管からさらに筋緎維へと分化する.

コートしたシャーレの中でサブコンフルエント（シャー レの全面をほぼ覆うほど増殖した状態）まで培養し，培 地を増殖培地から分化培地に換えると, 細胞増殖が停止 して分化が誘導される ${ }^{(2)}$. 増殖培地と分化培地に含まれ る血清の種類と濃度は大きく異なり，それぞれウシ胎仔 血清 (10〜20\%)，ウマ成体血清（1２\%）が用いられる.

株化筋芽細胞は実質的にいくらでも増やすことがで き，保存も容易である. しかし，同じ名前の株化細胞で も研究室が異なると分化能には大きな違いがあり, 細胞 融合がほとんど進まない場合もある。分化能の高いク ローンを選び，培養開始から少ない経代数のうちに分化 誘導する工夫が効率の良い分化には必要である。 それで 屯多くの場合，小さな筋管が形成されるにとどまる，初 代培養筋芽細胞から筋繊維をつくるのは比較的容易であ るが，細胞採取のために生体を傷つける必要がある上， 筋芽細胞以外の細胞種が混ざるのは避けがたく，再現性 良く細胞を調製することは簢単ではない.

筋管が形成されるときは，すべての筋芽細胞が融合に 加わるのではなく, 一部の細胞はアポトーシスを起こし て死ぬ。この現象は 1 世紀以上前にすでに観察されてお $り^{(3)}$, 同様の現象はシャーレの中の培養筋芽細胞につい ても見られていた。 ただし，亡゙のようにして死めのかは ほとんどわかっていなかった。 アポトーシスはカスパー ゼ・プロテアーゼファミリーによって実行される。 カス パーゼは高等動物の細胞内に 10 種類ほよ゙常時存在して 


\section{今日の話題}

おり，そのうちの 4,5 種類が組となって少なくとも 3 つ の活性化カスケードを形成している ${ }^{(4)}$. アポトーシスの 起こるきっかけはいろいろあり，たとえば細胞外から来 るアポトーシス促進因子，栄養枯渴がそれぞれ特異的な カスパーゼ・カスケードを起動して細胞を死に至らしめ る.

細胞内でつくられるタンパク質のうち半分程度は小胞 体を通過し，その間に立体構造を形成する。何らかの原 因で小胞体内に構造異常タンパク質が蓄積した状態を小 胞体ストレスといい，アポトーシスをひき起こすことが ここ 10 年ほどの間に明らかにされてきた。 小胞体スト レスによって特異的に起動するカスケードについてはマ ウスを用いた研究が進んでおり，カスパーゼ 12 を起点 とするカスケードが活性化していることが示唆されてい $3^{(5,6)}$. カスパーゼ 12 がマウス肧の筋組織に多く発現し ていることから，筋繊維形成に伴うアポトーシスとこの プロテアーゼの関係が調べられた。 マウス肧で筋繊維形 成が始まる胎生 13.5 日の時期にカスパーゼ 12 の発現上 昇が起こり，アポトーシスを起こしている細胞ではカス パーゼ 12 が活性化していることが判明した ${ }^{(7)}$. カス パーゼ 12 の活性化は小胞体ストレスが生じていること を強く示唆しており，実際に，同じ時期にストレス応答 タンパク質の発現上昇が起こる。カスパーゼ 12 の活性 化之小胞体ストレスマーカーの発現上昇は $\mathrm{C} 2 \mathrm{C} 12$ 細胞 の分化でも認められている。興味深いことに，小胞体ス トレスシグナル系を遮断する薬剤を用いて筋芽細胞を処 理すると，分化誘導培地中に打けるアポトーシスおよび 筋管の形成が著しく阻害される ${ }^{(7)}$. 分化中の筋芽細胞小 胞体内に構造異常夕ンパク質が蓄積しているか否かは不 明であるが，小胞体ストレスシグナルがアポトーシスや 筋分化を促進することが示唆される。

培養筋分化系でも小胞体ストレス(様)ストレスが生じ るが，培養条件を確立する上でストレスは考慮されてい ない，小胞体ストレスを付加してから分化誘導を行なう とどうなるのだろうか。，小胞体に存在する酵素の阻害剤 の中には小胞体ストレスをひき起こすものがある。この 阻害剤処理を短時間行なってから分化を誘導すると，筋 緎維形成効率，アポトーシスともに劇的に増えた ${ }^{(8)}$ 。そ して, 融合細胞あたりの核数，サイズとも 1 桁以上増大 し，筋原繊維を含み自立的収縮能を示す筋繊維細胞が多 数出現した（図 2)。ストレス処理がない場合には筋原繊 維は検出されず，収縮する細胞はほとんどない，また，
+ ストレス処理

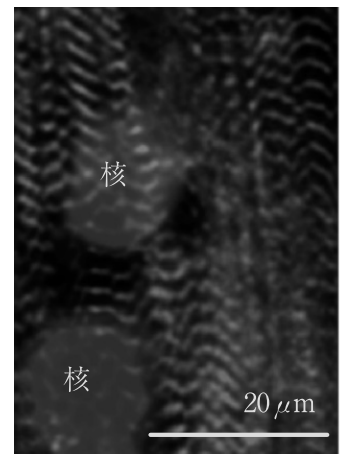

図 2 ・ ストレス処理後の細胞内に検出された筋原繊維 アクチン結合タンパク質の免疫染色によって, ストレス処理群 には筋原繊維の縞模様が見える。

処理しない場合に比べて短期間により多くの細胞でアポ トーシスが起こった，ストレス処理によって筋繊維形 成，アポトーシスともに効率が上昇したのである.

細胞培養では細胞を丁寧に取り扱うことが基本であ り, 熱, 乾燥, 圧力などといったショックを細胞に与え ないようにする気遣いが大事である。しかし，細胞分化 過程においては細胞構造, 遺伝子発現, タンパク質合成, 分解，分泌など細胞自身に様々な大変化が起こる。これ がある種のストレスとなり，小胞体で検知されているら しい. 小胞体ストレスが筋瀻維形成促進効果をもつこと は，ストレスが分化過程に組み込まれて役に立っている ことを示唆している．生体内での小胞体ストレス(様) ス トレスの実体を探ることとともに，筋分化系以外の分化 系においてストレスが何らかのポジティブな㗢きをして いるかどうか検討する価值がある.

1) R. A. DeFronzo, E. Jocot, E. Jequier, E. Maeder, J. Wahren \& J. P. Felber: Diabetes, 30, 1007 (1981).

2) F. E. Stockdale \& M. Holtzer:Exp. Cell Res., 24, 508 (1961).

3) E. Godlewski : Arch. mikr. Anat., 60, 111 (1902).

4) K. F. Ferri \& G. Kroemer: Nature Cell Biol., 3, E255 (2001).

5) T. Nakagawa, H. Zhu, N. Morishima, E. Li, J. Xu, B. A. Yankner \& J. Yuan : Nature, 403, 98 (2000).

6) N. Morishima, K. Nakanishi, H. Takenouchi, T. Shibata \& Y. Yasuhiko: J. Biol. Chem., 277, 34287 (2002).

7) K. Nakanishi, T. Sudo \& N. Morishima : J. Cell Biol., 169, 555 (2005)

8) K. Nakanishi, N. Dohmae \& N. Morishima:FASEB J., 21, 2994 (2007).

（森島信裕, 中西慶子, 理化学研究所中央研究所） 